A Journal of Agricultural Science Published by the California Agricultural Experiment Station

\title{
HOT-WATER TREATMENT OF GLADIOLUS CORMELS FOR THE ERADICATION OF
}

FUSARIUM OXYSPORUM F. GLADIOLI

CHESTER N. ROISTACHER, KENNETH F. BAKER, and J. G. BALD

\section{2,3,5-TRIPHENYLTETRAZOLIUM CHLORIDE AS AN INDICATOR OF GERMINABILITY AND DORMANCY OF GLADIOLUS CORMELS \\ CHESTER N. ROISTACHER, J. G. BALD, and KENNETH F. BAKER}

This number completes Volume 26 


\title{
2,3,5-TRIPHENYLTETRAZOLIUM CHLORIDE AS AN INDICATOR OF GERMINABILITY AND DORMANCY OF GLADIOLUS CORMELS
}

\author{
CHESTER N. ROISTACHER, ${ }^{2}$ J. G. BALD, ${ }^{3}$ and KENNETH F. BAKER ${ }^{3}$
}

\section{INTRODUCTION}

DURING TRIALS of hot-water treatment of gladiolus cormels (Roistacher, Baker, and Bald, 1957 $)^{4}$ it appeared that a method for quickly determining the stage of dormancy of cormels might make it possible to treat them effectively without injury or without prolonging dormancy. The chemical 2,3,5triphenyltetrazolium chloride was investigated as a possible indicator of cormel dormancy.

2,3,5-triphenyltetrazolium chloride $\mathrm{e}^{5}$ is a water-soluble colorless salt that forms insoluble carmine red triphenyl formazan when in a reduced state. It has been extensively investigated as an indicator of high metabolic activity in a variety of plant and animal tissues, since the property of turning red in active metabolizing tissue was first reported by Kuhn and Jerchel (1941).

It has had wide use on many kinds of seeds as an index of germinability, since the method was introduced for this purpose by Lakon $(1942 a, b)$. The literature on this use has been reviewed by Porter, Durrell, and Romm (1947), Flemion and Poole (1948), and Smith (1951). A good correlation generally has been noted between the appearance of red coloration in the embryos and the percentage germination in a given lot of seed, but numerous factors must be taken into account for successful commercial application to a specific plant. The general method has also been adapted to measure the damage (reduced germinability) to seeds from freezing (Goodsell, 1948; Bennett and Loomis, 1949; Parker, 1953), excessive heating (Fuchs and Beiler, 1943, 1948; Brewer, 1949; Macleod, 1950; Lambou, 1953), drying (Brewer, 1949 ; Parker, 1953), and cathode rays (Lambou, 1953), as well as probable ability to grow in cold soil (Germ and Kietreiber, 1954).

Tetrazolium salts have also been used to measure vitality of plant tissues other than seeds. Mattson, Jensen, and Dutcher (1947) found that TTC would stain tissue from the fleshy part of apples, oranges, and grapes, mushroom gills, carrot roots, white and sweet potatoes, young leaves, and stigmas and ovaries of pollinated flowers, as well as animal tissue. Waugh (1948) tested dormant twigs of several kinds of trees, and found that TTC stained the cambial layers. Twigs killed by heat gave no reaction. Dufrenoy and Pratt (1948) showed that the upper nodes of sugar cane stems reduced TTC.

${ }^{1}$ Received for publication May 9, 1956.

${ }^{2}$ Senior Laboratory Technician, Agricultural Experiment Station, Los Angeles, now Principal Laboratory Technician, Department Plant Pathology, Citrus Experiment Station, Riverside.

${ }^{3}$ Plant Pathologists, Agricultural Experiment Station, Los Angeles.

"See "Literature Cited" for citations, referred to in the text by author and date.

${ }^{5}$ Referred to in this paper as TTC or tetrazolium. 
The degree of blanching of edible parts of several vegetables from heat was measured with TTC by Morse (1949). Roberts (1950) investigated stem and root tissues of 35 species of monocots, dicots, and ferns for TTC-reducing activity. In dicots, apical meristems of terminal and lateral buds and roots, as well as some lateral meristems were stained; in monocots, intercalary meristems and nodes were stained. Parker $(1953,1955)$ demonstrated TTCreducing activity for meristematic tissue of pine leaves, stems, and roots, and for root tips of corn and onion.

The staining oi microörganisms by TTC has been demonstrated for algae (Dyar, 1953 ; Parker, 1953), bacteria (Kuhn and Jerchel, 1941; Huddleson and Baltzer, 1950; Somerson and Morton, 1953), yeasts (Kuhn and Jerchel, 1941; Gunz, 1949; Currier and Day, 1954), actinomycetes (Fults, Schaal, and Michaelson, 1949), and Penicillium (Fred and Knight, 1949). Plant tissues invaded by several viruses were also shown to reduce TTC (Beal, Preston, and Mitchell, 1955).

Because of the versatility of TTC for measuring metabolic vitality in normal and injured tissue, tests were conducted to see whether it could be used to measure: 1) the probable tolerance of gladiolus cormels to heat treatment, and 2) the level of dormancy of cormels. A technique was developed to evaluate the degree of reddening of cormel tissues under standard conditions (Roistacher, Bald, and Baker, 1953). It was subsequently used by Tsukamoto (1954) to indicate dormancy of corms as affected by heat treatment at $95^{\circ}$ to $100^{\circ} \mathrm{F}$. The present paper will report: 1) the background of the experimental procedure; 2 ) some correlations beween TTC reddening and germination; 3 ) association between cold storage, tetrazolium reddening, and cormel germination; 4) points to be considered in using TTC as a test for dormancy in gladiolus cormels.

\section{A TECHNIQUE FOR MEASURING THE COLOR REACTION OF CORMEL TISSUE}

At first, cormels were cut in half and dipped in a 1 per cent solution of TTC in tap water of $\mathrm{pH} 7.9 .^{\circ} \mathrm{A}$ distinct reddening was noted in the meristematic region through the central portion of the cormel. Check cormels placed in water, or those boiled in water and placed in the TTC solution, did not show any reddening. A number of different varieties were tested and it was soon apparent that some varieties reddened faster than others. The technique was modified by placing the split cormels on a disk of moistened filter paper in a Petri dish in diffuse light. Numerical ratings were given to the various shades of pink and red formed in the central meristematic region and the parenchymatous tissues.

The following method was based on modifications of earlier tests and used as standard procedure for experiments reported here. The description is quoted from a previous summary of this work (Roistacher, Bald, and Baker, 1953).

"(1) A 1\% aqueous solution of 2,3,5-triphenyltetrazolium chloride is prepared and kept in a stoppered bottle in the dark at room temperature.

- The water should not have a $\mathrm{pH}$ of less than about 6.5 , nor more than about 9.0 (Jámbor, 1954 ; Jámbor and Mester, 1955). 


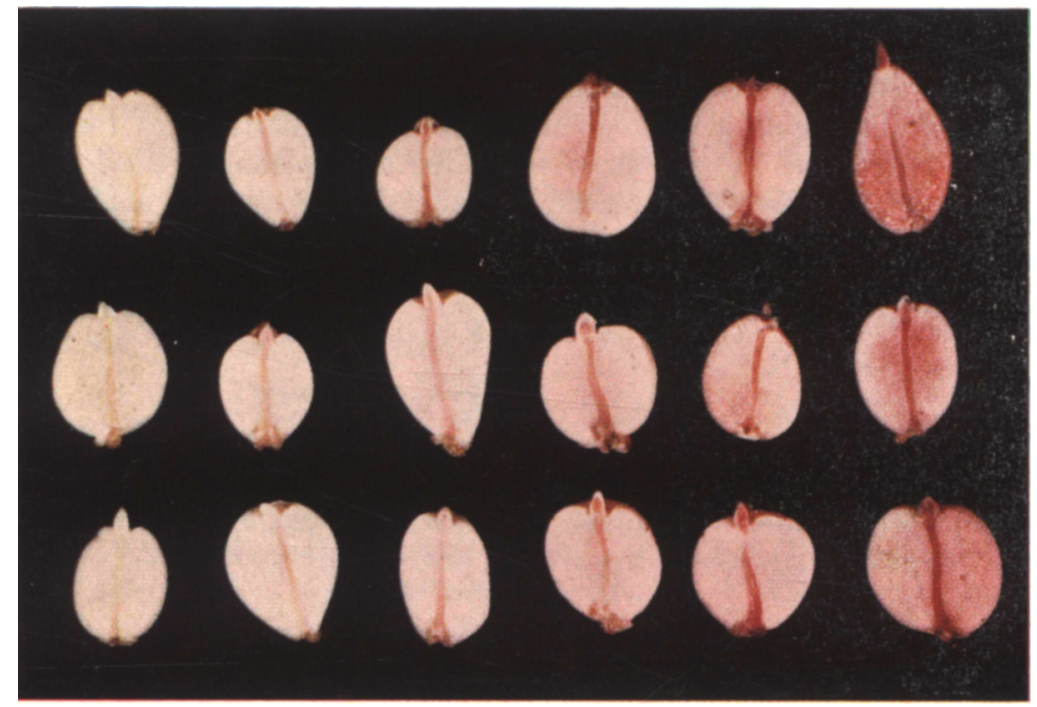

Fig. 1. Kodachrome photograph of cut surfaces of cormels exposed for 4 hours to TTC, showing the five numerical ratings based on the varying degrees of tetrazolium reddening. 0 at left, to 5 at right. Some varieties under certain conditions tend to give slightly more intense color than shown here. 
(2) A single sheet of filter paper is placed in each of 2 Petri dishes and soaked with solution. The minimum amount required is about $21 / 2 \mathrm{ml}$. per dish. The prepared dishes are kept in the dark if not used immediately. (3) Duplicate lots of 20 cormels, representative of the stock under test, are peeled (i.e., the dry husk is removed) and cut longitudinally with a razor blade to expose the central vascular region on one or both halves. Recent tests suggest that peeling may be unnecessary if a little extra tetrazolium solution is put in the Petri dish to allow for absorption by the husks. (4) Each pair of half cormels is placed radially on the outside border of the

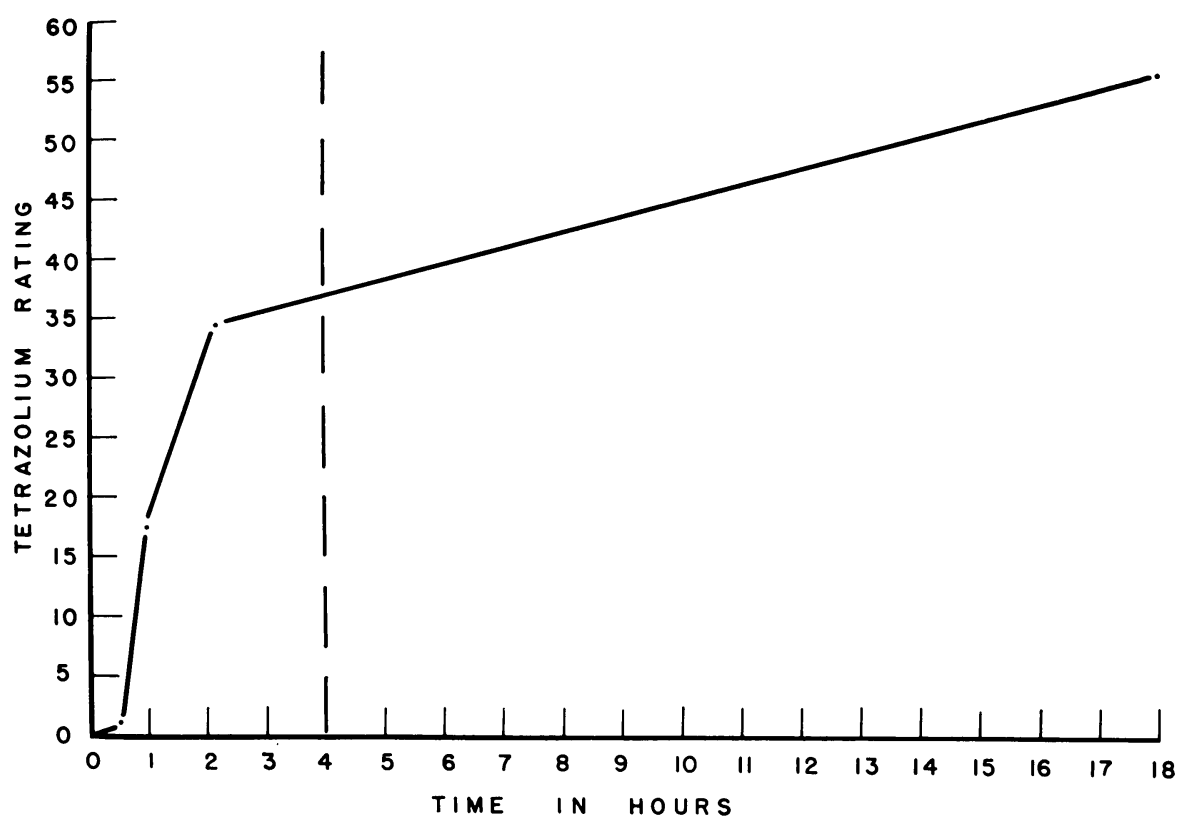

Fig. 2. The average intensity of reddening for eight gladiolus varieties over a period of 18 hours at $70^{\circ} \mathrm{F}$. A 4 -hour contact period between the cormel and the 1 per cent solution of the tetrazolium salt was adopted as standard in all subsequent tests.

filter paper, cut surface down. Twenty pairs about fill the perimeter of the paper. Two dishes are thus prepared, each from one of the duplicate lots of 20 cormels. (5) The dishes are placed in the dark at approximately $70^{\circ} \mathrm{F}$ to incubate for $4 \mathrm{hr}$. (6) The cormels are rated according to the extent and intensity of the red color developing in the vascular region through the center of the cormel, and any additional coloration throughout the storage tissues (fig. 1). The rating given for the whole cormel is that of the half cormel with the more pronounced coloration. The rating standard may be described as follows. A value of 0 is given to a cormel when there is no observable pink or red color from the dye; a faint coloration along the central vascular strand is rated 1 ; medium to strong color of the vascular strand, 2; strong color of the vascular strand plus some coloration throughout part of the parenchymatous storage tissues, 3 ; intense coloration of the central strand and medium coloration throughout most of the parenchymatous 
tissues, 4 ; and intense coloration over the whole surface, 5 . The sums of the ratings, which range between 0 and 100 for a single dish, give an estimate of the mean germinability of the lot of corms from which the duplicate samples are taken."

A 4-hour period was chosen as standard for incubating the cormel as a result of many tests on a number of varieties. Figure 2 shows the increase of color ratings as average values for eight varieties. After 3 hours further increase in intensity of coloring generally was very slow. A cormel showing a strong pink coloration at 4 hours appeared the same or perhaps only a little darker after 18 hours. It was concluded that if reddening was to occur, the majority of cormels would show it within 4 hours. Lambou (1953) reports using a 2 per cent solution and a 4-hour interval to achieve maximum reddening of cotton seed.

\section{CONSISTENCY AND ACCURACY OF TETRAZOLIUM RATINGS}

To test the uniformity of judgment by different observers, ratings for 40 cormels have been made by several people on a number of occasions, using the color chart (fig. 1) without further instructions. A very high degree of uniformity between ratings has been observed in all these tests.

In making records, the ratings were recorded in a table as follows, as each cormel was examined.

\begin{tabular}{cccc}
\multicolumn{5}{c}{ Sample 1 } \\
3 & 3 & 1 & 2 \\
1 & 2 & 2 & 2 \\
2 & 3 & 2 & 3 \\
4 & 3 & 3 & 2 \\
2 & 2 & 5 & 3 \\
$\frac{1}{12}$ & $\frac{1}{13}$ & $\frac{-}{13}$ & $\frac{1}{12}=50$
\end{tabular}

\begin{tabular}{ccccc}
\multicolumn{5}{c}{ Sample 2 } \\
4 & 1 & 4 & 2 \\
3 & 3 & 2 & 2 \\
2 & 2 & 3 & 1 \\
5 & 3 & 2 & 3 \\
3 & 4 & 5 & 2 \\
$\frac{1}{17}$ & $\frac{1}{13}$ & $\frac{1}{16}$ & $\frac{1}{10}=56$
\end{tabular}

By taking the mean of the two totals, a value was obtained (53), which gave an estimate of reddening for the sample on a 100-unit scale. This mean represents the total numerical rating for 20 cormels, and is used as a standard of comparison. Where more or less than 20 were used, the total was prorated to 20 . The data from such a table were then assembled in a frequency series.

\begin{tabular}{|c|c|c|c|}
\hline Degree of reddening & $\begin{array}{ccc}0 & 1 & 2 \\
- & - & -\end{array}$ & 3 & 4 \\
\hline \multirow{2}{*}{ Number of cormels } & $\begin{array}{llll}0 & 4 & 16\end{array}$ & 13 & 4 \\
\hline & 20 & & 20 \\
\hline
\end{tabular}

Adding the frequencies for ratings 0 to 2 and 3 to 5 gave two values, separated on the basis of whether any coloration observed was restricted to the central vascular tissue, or whether it was present in both the vascular and parenchymatous tissues. The frequency series and the division of ratings into two categories gave a second method of estimating tetrazolium reddening, which has been particularly useful in judging cases where the frequency series was obviously skewed or heterogeneous. 


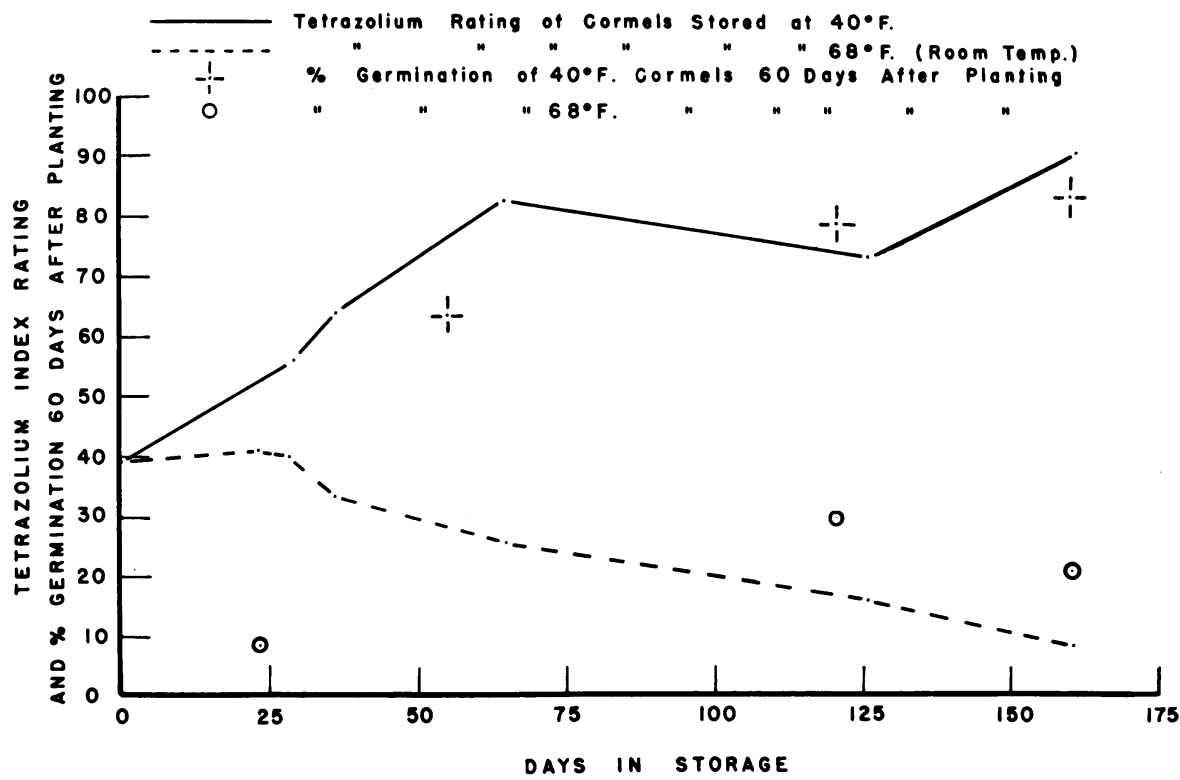

Fig. 3. The relationship between the degree of tetrazolium reddening and germination of dormant and nondormant cormels of variety Margaret Beaton. Cormels were divided into two lots-one held in cold storage $\left(40^{\circ} \mathrm{F}\right)$ and the other at room temperature $\left(68^{\circ} \mathrm{F}\right)$. Germination 60 days after planting is compared with the tetrazolium rating on the same scale.

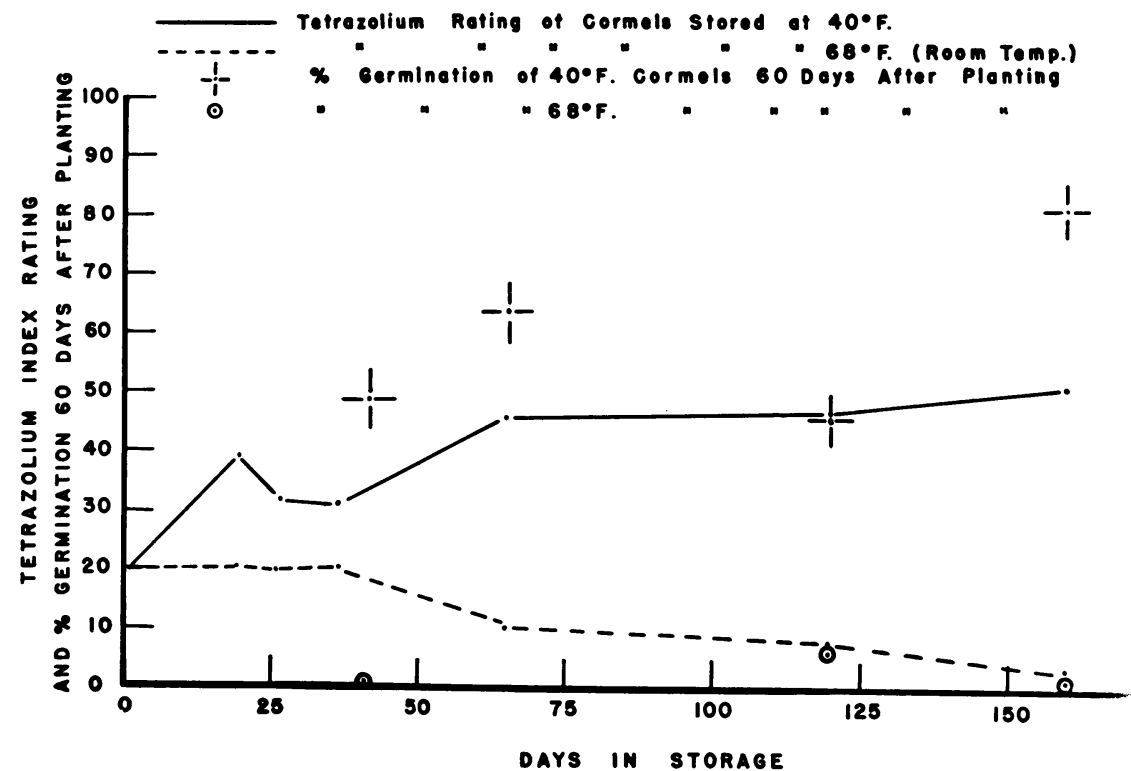

Fig. 4. The relationship between the degree of tetrazolium reddening and germination of dormant and nondormant cormels of variety Leading Lady. Cormels were divided into two lots-one held in cold storage $\left(40^{\circ} \mathrm{F}\right)$ and the other at room temperature $\left(68^{\circ} \mathrm{F}\right)$. Germination 60 days after planting is compared to the tetrazolium rating on the same scale. 


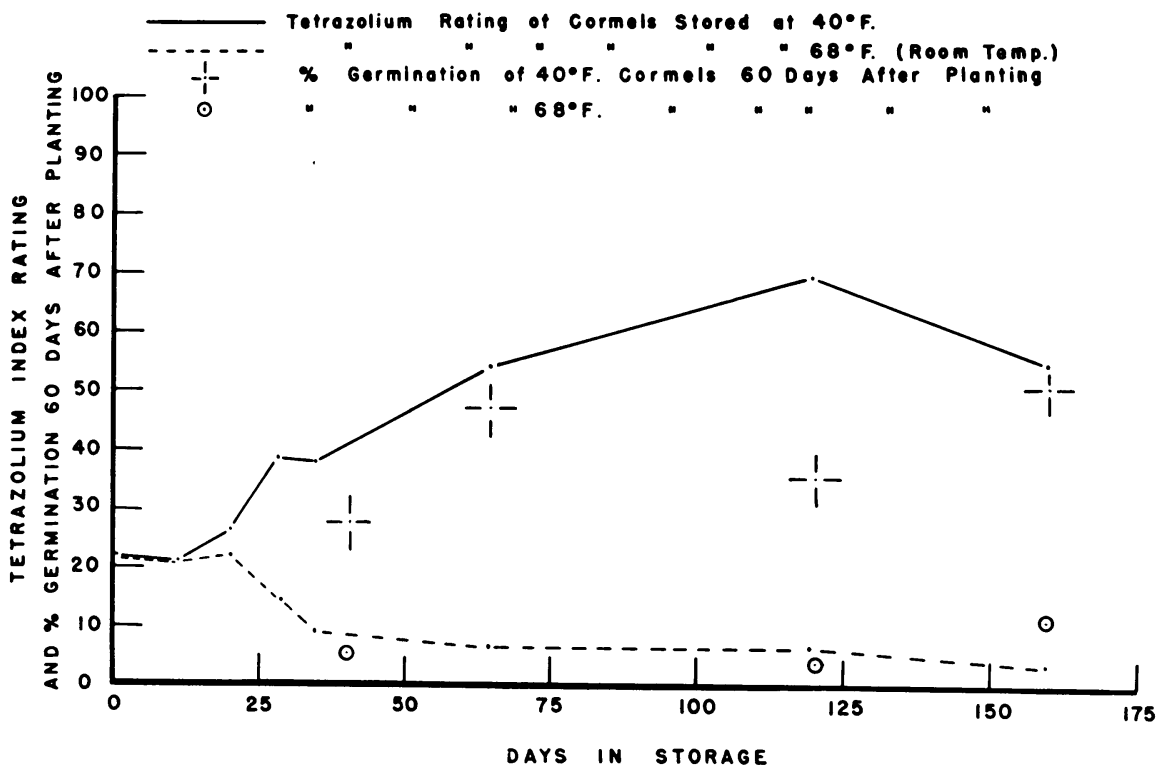

Fig. 5. The relationship between the degree of tetrazolium reddening and germination of dormant and nondormant cormels of variety Valeria. Cormels were divided into two lots-one held in cold storage $\left(40^{\circ} \mathrm{F}\right)$ and the other at room temperature $\left(68^{\circ} \mathrm{F}\right)$. Germination 60 days after planting is compared to the tetrazolium rating on the same scale. (See also tables 2 and 3.)

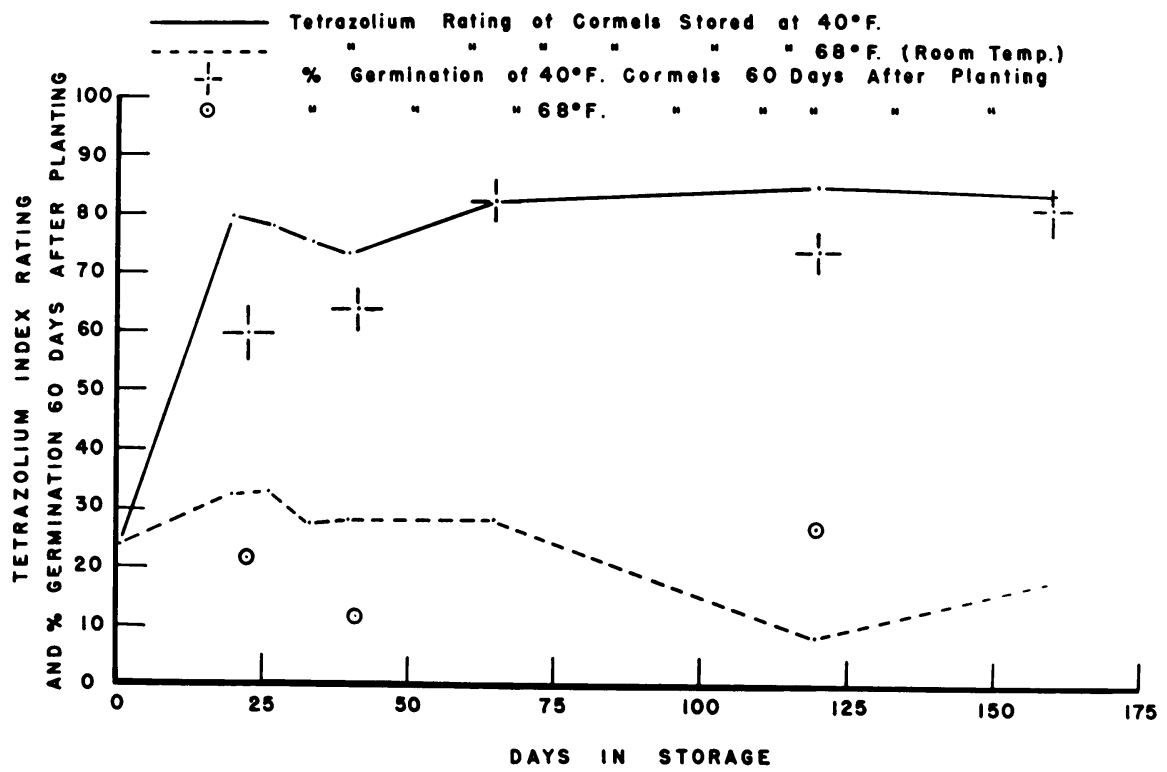

Fig. 6. The relationship between the degree of tetrazolium reddening and germination of dormant and nondormant cormels of variety Elizabeth the Queen. Cormels were divided into two lots-one held in cold storage $\left(40^{\circ} \mathrm{F}\right)$ and the other at room temperature $\left(68^{\circ} \mathrm{F}\right)$. Germination 60 days after planting is compared to the tetrazolium rating on the same scale. 
Analysis of variance of the date from the table on page 689 gave an estimate of the accuracy of the mean rating. The least significant difference between ratings for two lots of $\mathbf{4 0}$ cormels having this degree of variability would be less than 10 units on the 100-unit scale.

$\begin{array}{lrrr}\text { Blocks } & 1 & 0.9 & 0.90 \\ \text { Error } & 38 & 42.2 & 1.11\end{array}$

Least significant difference between two lots of 40 cormels would be about 0.475 unit on the 5-unit scale.

The following analysis of variance indicates the variability to be expected in a series of seven experiments using four varieties. The data consisted of readings from 1,120 cormels of four varieties submitted to cold storage, and sampled on seven occasions. They represent parts of the data from a large experiment discussed later (figs. 3 to 6 ). There were significant differences between varieties and between occasions, and differences between varieties varied from one occasion to another. The residual variance, with 1,092 degrees of freedom, provided an estimate of the least significant difference between two lots of 40 cormels $=6.32$ units on the 100-unit scale.

$\begin{array}{lrrr}\text { Varieties } & 3 & 138.332 & 46.111 \\ \text { Occasions } & 6 & 170.337 & 28.389 \\ \text { Varieties } \times \text { Occasions } & 18 & 43.334 & 2.407 \\ \text { Error } & 1,092 & 546.665 & 0.501\end{array}$

Least significant difference between mean of two lots of 20 cormels, 6.316 units on the 100-unit scale.

These two instances provide examples of the accuracy of tetrazolium ratings for reasonably uniform material. The level of variability may be somewhat higher if less uniform samples of cormels are rated, but if samples are properly chosen it is seldom much higher than 10 per cent.

\section{COMPARISON OF THE DEGREE OF TETRAZOLIUM REDDENING WITH GERMINATION POTENTIAL OF CORMELS}

\section{Preliminary Tests}

Preliminary tests run in conjunction with hot-water treatments are shown in table 1. Where the majority of cormels has a low TTC rating ( 0 to 2$)$, germination is low (variety Beneson); where most TTC ratings are high, germination is high (varieties Myrna Fay, 2; and one-year-old Picardy, 1) and where ratings are intermediate, germination is intermediate (varieties Myrna Fay, 1; and three-month-old Picardy, 2). A time interval of 60 days after planting was chosen as a standard to compare the per cent germination with the tetrazolium rating in further tests reported in this paper.

\section{Correlations of TTC Rating with Germination}

A series of experiments was begun to test the possibility of predicting cormel germination by the use of the tetrazolium test. Earlier tests revealed that if cormels showing a low rating were placed in cold storage, they would show a higher rating and a higher per cent germination after a time (table 1, variety Myrna Fay). An attempt was made to correlate the degree of redden- 
TABLE 1

\section{EXAMPLES OF SOME EARLY COMPARISONS BETWEEN TTC RATINGS AND GERMINABILITY}

\begin{tabular}{|c|c|c|c|c|c|c|c|}
\hline \multirow{3}{*}{ Variety } & \multicolumn{4}{|c|}{ Tetrazolium test } & \multicolumn{3}{|c|}{ Germination } \\
\hline & \multirow{2}{*}{$\underset{\text { treatment }}{\text { Cormel }}$} & \multicolumn{2}{|c|}{$\begin{array}{l}\text { Frequency rating of } \\
\text { single cormels }\end{array}$} & \multirow{2}{*}{$\begin{array}{l}\text { Rating } \\
\text { for } 20 \\
\text { cormels }\end{array}$} & \multirow{2}{*}{$\begin{array}{l}\text { Number } \\
\text { cormels } \\
\text { planted }\end{array}$} & \multirow{2}{*}{$\begin{array}{c}\text { Number } \\
\text { days after } \\
\text { planting }\end{array}$} & \multirow{2}{*}{$\begin{array}{c}\text { Germina- } \\
\text { tion } \\
\text { per cent }\end{array}$} \\
\hline & & $0-2$ & $3-5$ & & & & \\
\hline $\begin{array}{l}\text { Picardy } \\
1\end{array}$ & $\begin{array}{l}10 \text { cormels, } \\
\text { examined in } \\
\text { early tests }\end{array}$ & 2 & 8 & 80 & 100 & 45 & 61 \\
\hline \multirow[t]{2}{*}{ Beneson } & \multirow[t]{2}{*}{ Dry, unpeeled } & \multirow[t]{2}{*}{38} & \multirow[t]{2}{*}{2} & \multirow[t]{2}{*}{21} & $50^{*}$ & 45 & 4 \\
\hline & & & & & 2000 & 60 & 0 \\
\hline \multirow{2}{*}{$\begin{array}{l}\text { Myrna Fay } \\
1\end{array}$} & \multirow[t]{2}{*}{ Dry } & \multirow[t]{2}{*}{30} & \multirow[t]{2}{*}{10} & \multirow[t]{2}{*}{36.5} & $50^{*}$ & 45 & 40 \\
\hline & & & & & 200 & 46 & 48 \\
\hline $\begin{array}{l}\text { Myrna Fay } \\
2\end{array}$ & $\begin{array}{l}\text { Cold storage } \\
3 \text { weeks }\end{array}$ & 6 & 34 & 85 & 50 & 41 & 78 \\
\hline $\begin{array}{l}\text { Picardy } \\
2\end{array}$ & $\begin{array}{l}\text { Soaked } \\
\text { overnight }\end{array}$ & 11 & 9 & 56 & 100 & 44 & 34 \\
\hline
\end{tabular}

* Separate tests were made for each of these samples.

TABLE 2

TETRAZOLIUM RATINGS OF CORMELS OF VARIETY VALERIA STORED FOR VARYING PERIODS OF TIME IN COLD STORAGE AND AT ROOM TEMPERATURE. SEE ALSO FIGURE 5 AND TABLE 3

\begin{tabular}{|c|c|c|c|c|c|c|c|c|c|c|c|c|c|c|c|}
\hline \multirow{4}{*}{ Date of test } & \multirow{4}{*}{$\begin{array}{l}\text { Days in } \\
\text { storage }\end{array}$} & \multicolumn{14}{|c|}{ Tetrazolium ratings } \\
\hline & & \multicolumn{7}{|c|}{ Cormels stored at room temperature } & \multicolumn{7}{|c|}{ Cormels stored at $40^{\circ} \mathrm{F}$} \\
\hline & & \multicolumn{6}{|c|}{ Tetrazolium index } & \multirow{2}{*}{$\begin{array}{l}\text { Rating } \\
\text { for } 20 \\
\text { cormels }\end{array}$} & \multicolumn{6}{|c|}{ Tetrazolium index } & \multirow{2}{*}{$\begin{array}{l}\text { Rating } \\
\text { for } 20 \\
\text { cormels }\end{array}$} \\
\hline & & 0 & 1 & 2 & 3 & 4 & 5 & & 0 & 1 & 2 & 3 & 4 & 5 & \\
\hline $3 / 14 / 51 \ldots$ & 0 & 15 & 15 & 4 & 4 & 1 & 1 & 22.0 & . & . & .. & . & . & .. & $\ldots$ \\
\hline $3 / 26 / 51$ & 12 & 0 & 39 & 0 & 1 & 0 & 0 & 21.0 & 0 & 39 & 0 & 1 & 0 & 0 & 21.0 \\
\hline $4 / 4 / 51 \ldots$ & 21 & 0 & 31 & 6 & 3 & 0 & 0 & 22.0 & 0 & 31 & 6 & 3 & 0 & 0 & 26.0 \\
\hline $4 / 11 / 51 \ldots \ldots \ldots$ & 28 & 19 & 16 & 3 & 2 & 0 & 0 & 14.0 & 0 & 22 & 3 & 7 & 7 & 1 & 37.5 \\
\hline $4 / 18 / 51 \ldots \ldots$ & 35 & 26 & 12 & 2 & 0 & 0 & 0 & 8.0 & 0 & 19 & 10 & 8 & 3 & 0 & 37.5 \\
\hline $5 / 18 / 51 \ldots \ldots$ & 65 & 29 & 9 & 2 & 0 & 0 & 0 & 6.5 & 0 & 5 & 17 & 9 & 5 & 4 & 53.0 \\
\hline $7 / 12 / 51 \ldots \ldots \ldots \ldots$ & 120 & 27 & 13 & 0 & 0 & 0 & 0 & 6.5 & 0 & 0 & 4 & 20 & 10 & 6 & 69.0 \\
\hline $8 / 22 / 51 \ldots \ldots \ldots \ldots$ & 161 & 36 & 2 & 1 & 1 & 0 & 0 & 3.5 & 3 & 7 & 4 & 14 & 9 & 3 & 54.5 \\
\hline
\end{tabular}

ing of the cormels at any given time with the germination of sister cormels planted at the same time.

Cleaned cormels of four varieties grown at Oceanside, California, and dug in early December, 1950, were obtained from a grower in early March, 1951. These were run through a $1 / 4$-inch screen to eliminate the very small ones and provide a more uniform sample. They were then washed and soaked in water; any rotted ones floating to the top were skimmed off. The four varieties used 
were: Elizabeth the Queen, Leading Lady, Margaret Beaton, and Valeria. All had fairly thick husks that were not cracked, with the exception of Margaret Beaton which had approximately 15 per cent cracked husks.

After the cormels were well dried, a tetrazolium test was conducted on each of the four varieties. The cormels were then separated into two equal lots. On March 14, one lot was placed in a cold storage cabinet held at $40^{\circ} \mathrm{F}$

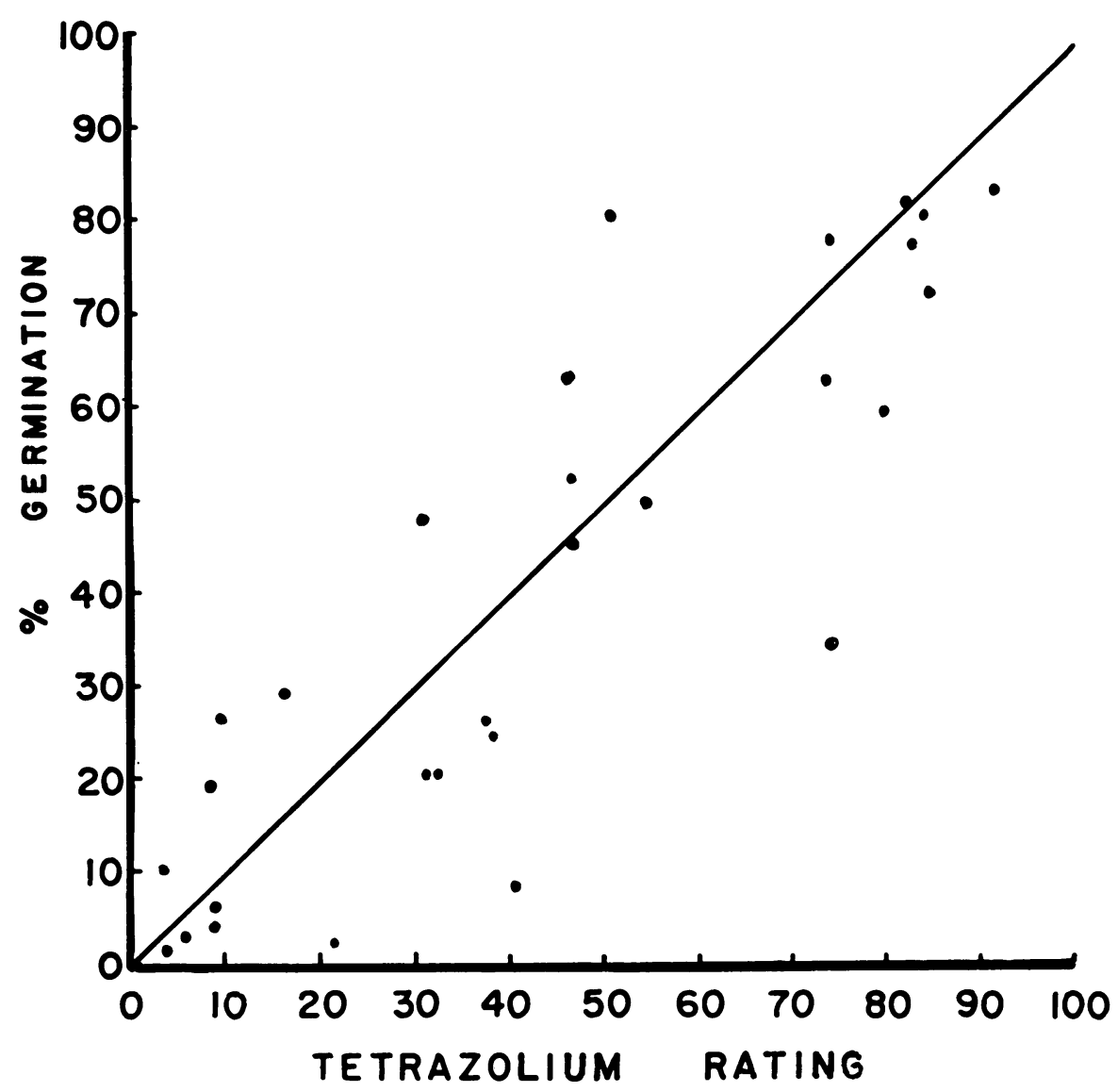

Fig. 7. Scatter diagram showing the correlation of 29 separate tests on a number of different varieties, plotting the per cent germination 60 days after planting against the tetrazolium rating.

and the other left at room temperature (approximately $68^{\circ} \mathrm{F}$ ). Tetrazolium tests of cormels in cold storage and those at room temperature were taken at varying intervals from March through August, 1951. Plantings were made at varying intervals coinciding with the tetrazolium tests. Two hundred cormels of each variety were planted each time in four replicates of 50 each, and germination counts taken weekly. The per cent germination after 60 days was used for comparison with the tetrazolium rating.

Table 2 shows the tetrazolium ratings and germination results for the variety Valeria. Figures 3 through 6 show the results for each of the four 
varieties in graphic form. The curves represent the tetrazolium rating as plotted against time in storage at $68^{\circ}$ and $40^{\circ} \mathrm{F}$. The crosses and circles represent individual germination counts taken 60 days after planting, and are plotted according to the day of planting.

It is apparent from figures 3 to 8 that there is a correlation between the degree of reddening and the germinability of cormels kept in cold storage or

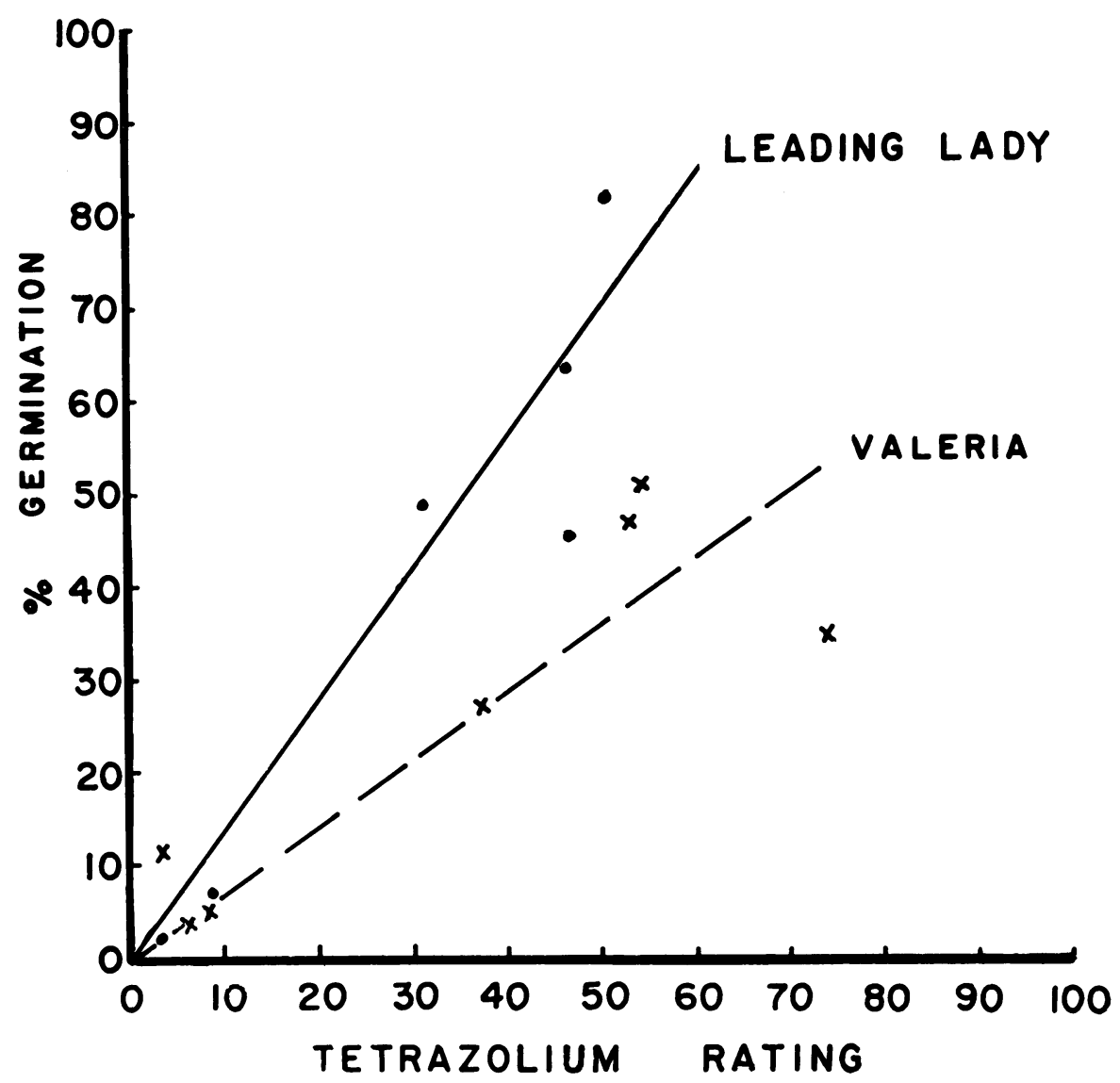

Fig. 8. Correlation of tetrazolium rating and germination of cormels plotted for 12 tests of two varieties, showing their differing slope. These differences are significant at the 5 per cent level. The solid line and the dots represent the variety Leading Lady, the broken line and crosses represent Valeria.

at room temperature. These results also suggest that under conditions similar to those imposed in this trial, germinability can be estimated approximately from the tetrazolium color rating.

Figure 7 shows a scatter diagram of tetrazolium ratings plotted against per cent germination. These represent results of many experiments with a number of varieties. There is an obvious correlation between the two quantities. However, when values for individual varieties are plotted as in figure 8 , a closer association is evident within varieties, and there appear to be differences between varieties in the regression of germination on tetrazolium 
rating. Statistical analysis of all the data in figure 7 shows differences in the slope of varietal curves to be significant at the 5 per cent level. The values for Leading Lady plotted in figure 8 indicate that, although cormels did not in any trial react with intense reddening, those with moderate tetrazolium ratings gave high percentage germination. The tendency for Valeria was lower germination for equivalent tetrazolium ratings. Subsequent experience has suggested some degree of varietal consistency in these relations. So far, however, varietal differences have not seriously affected the use of the tetrazolium method either in experimental work or in estimating the germinability of commercial lots of cormels. As experience accumulates, varietal characteristics can be taken increasingly into account in estimating germinability from tetrazolium ratings.

TABLE 3

GERMINATION RESULTS OF CORMELS OF VARIETY VALERIA STORED FOR VARYING PERIODS OF TIME IN COLD STORAGE AND AT ROOM TEMPERATURE. SEE ALSO FIGURE 5 AND TABLE 2

\begin{tabular}{|c|c|c|c|c|c|c|c|}
\hline \multirow{3}{*}{ Date planted } & \multirow{3}{*}{$\begin{array}{l}\text { Days in } \\
\text { storage }\end{array}$} & \multirow{2}{*}{\multicolumn{3}{|c|}{$\frac{\text { Cormels stored at room temperature }}{\begin{array}{c}\text { Per cent germination at indicated } \\
\text { days after planting }\end{array}}$}} & \multirow{2}{*}{\multicolumn{3}{|c|}{$\frac{\text { Cormels stored at } 40^{\circ} \mathrm{F}}{\begin{array}{c}\text { Per cent germination at indicated } \\
\text { days after planting }\end{array}}$}} \\
\hline & & & & & & & \\
\hline & & 20 & 40 & 60 & 20 & 40 & 60 \\
\hline $5 / 18 / 51$ & 41 & 0 & 2 & 5.0 & 0 & 11 & 27.0 \\
\hline $5 / 24 / 51 \ldots \ldots \ldots \ldots$ & 65 & . & .. & $\ldots$ & 4 & 40 & 47.0 \\
\hline $7 / 13 / 51 \ldots \ldots \ldots \ldots$ & 121 & 0 & 1 & 3.0 & 9 & 28 & 35.0 \\
\hline $8 / 23 / 51 \ldots \ldots \ldots \ldots$ & 162 & 0 & 2 & 11.5 & 7 & 23 & 50.5 \\
\hline
\end{tabular}

\section{CONSIDERATIONS IN USING TTC AS A TEST FOR DORMANCY}

Although the tetrazolium test can be a very valuable tool for rapidly determining germinability of dormant cormels, certain conditions which may modify the association between color rating and germinability should be understood.

\section{The Effect of Cracking and Thickness of the Outer Husk}

During preliminary tetrazolium tests the variety Miss Wisconsin showed a high tetrazolium rating, but when planted would not germinate. If, however, the outer husks were removed the cormels sprouted promptly (table 2 and fig. 9 of Roistacher, Baker, and Bald, 1957). Cormels of this variety had an especially thick, dark outer coat and apparently were unable to germinate because of this covering.

Cormels of the variety Margaret Beaton were segregated into two groupsthose whose outer coats appeared naturally cracked and those whose coats were uncracked. A tetrazolium test was taken of each sample, and 150 cormels were planted at the same time. Cormels whose husks had been naturally cracked had a TTC rating of 55.5 (with 75 per cent of the cormels rating 2 and 3 ), and after 60 days 48 per cent germinated. In the uncracked 
cormels the TTC rating was 28 (with 75 per cent of the cormels rating 1 ) and only 8 per cent germinated after 60 days. The cracked cormels showed a higher TTC rating and a higher per cent germination than uncracked ones. In other experiments, cracking the outer husks invariably resulted in an increased tetrazolium rating. An example may be cited from one experiment where the varieties Elizabeth the Queen and Valeria had a TTC rating of 24 and 22 , and 2 weeks after cracking showed a rating of 41.5 and 42.5 , respectively. Although corms with cracked husks usually show a higher tetrazolium rating than those with intact husks, recently dug cormels with thin and cracked husks have sometimes had very low ratings.

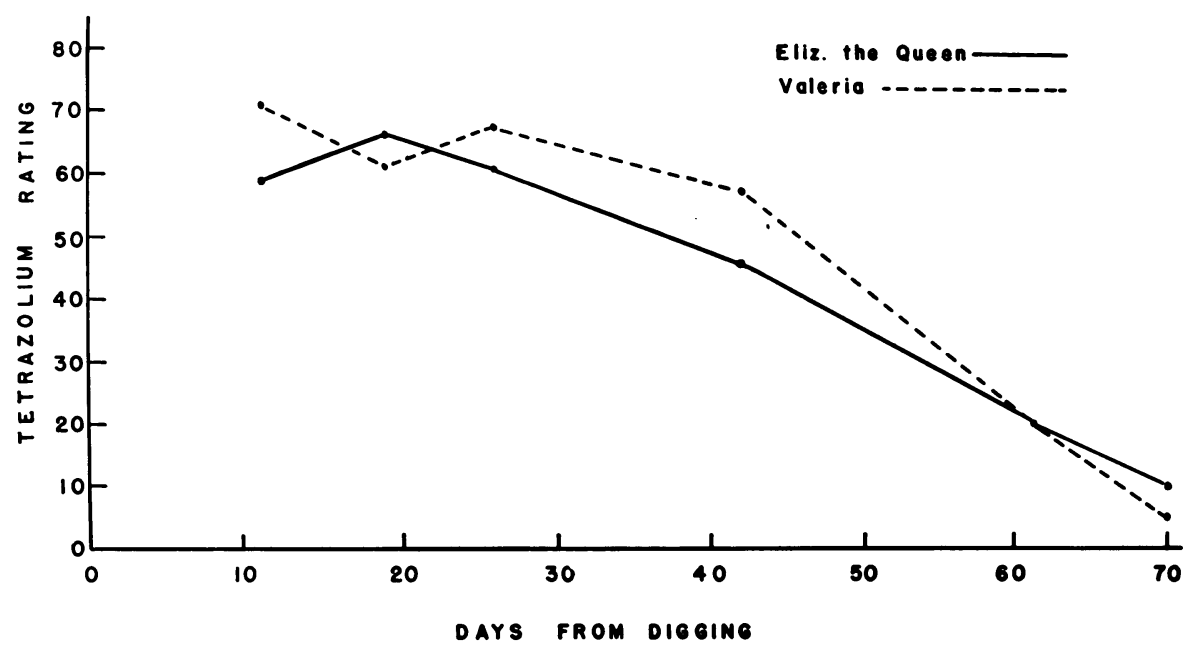

Fig. 9. The decline in tetrazolium reddening of two varieties held at room temperature $\left(68^{\circ} \mathrm{F}\right)$ over a period of 70 days following digging. The TTC test does not provide a valid measure of germinability during the early post-digging phase.

\section{The Effect of Time Following Digging}

At the time cormels are harvested the tetrazolium test reveals considerable physiological activity in the tissues, which is not associated with germinability. The color pattern differs from that observed later, centering mainly on the parenchymatous tissue and the outer cambial layer of the growing husk. As the husk dries and hardens the color reaction decreases. The decrease in reddening in two varieties of freshly dug cormels over a period of 70 days from digging is shown graphically in figure 9. Further trials over longer periods (Bald and Markley, unpublished data) support the indications of this experiment. As a measure of germinability the TTC color test should be applied only to cormels in the later phases of maturation.

\section{The Effect of Cormel Size}

The size of the cormel is definitely related to its level of dormancy. Denny and Miller (1934) showed this to be true when they divided freshly dug cormels of five varieties into four different sizes and found that the large 
sizes were less dormant than the small and very small ones and were, therefore, easier to bring out of dormancy by using ethylene chlorohydrin. In tetrazolium tests the larger cormels have repeatedly been found to show a higher degree of reddening than the smaller ones. This was noticed during preliminary tests when a large number of cormels were first peeled and lots of 20 cormels were then cut and placed in separate Petri dishes with TTC. There was an unconscious tendency to select the larger cormels first since they were easier to handle. As a result, the first 20 cormels cut and placed in the first Petri dish usually indicated a higher total rating than those in the second dish. This was remedied by grouping 20 cormels at a time before peeling and cutting. The importance of obtaining a representative sample of uniform-size cormels is evident.

\section{The Rate of Change in Degree of Tetrazolium Reddening}

The rate at which cormels lose their dormancy or show an increased tetrazolium rating will vary with the variety and conditions of storage or treatment. Some varieties (i.e., Leading Lady, fig. 4) may show a slow, steady climb in reddening while others (Elizabeth the Queen, fig. 6) may show a sudden increase over a short period of time. It is possible to visualize a situation where a tetrazolium test is taken on cormels while they are undergoing rapid internal change. A germination count taken on sister lots of these cormels 60 days later might show a much higher per cent germination than that predicted from the tetrazolium rating.

\section{DISCUSSION}

The original objective in devising the TTC color test for dormancy of gladiolus cormels was to find a quick method for determining the stage in which the cormels were most tolerant to hot-water treatment. Early treated lots which were tested by germination (Roistacher, Baker, and Bald, 1957) had shown that injury from hot-water treatment of dormant cormels was less extensive than to nondormant ones. The most desirable stage for treatment, which seemed to be the condition of maximum dormancy, was estimated by the tetrazolium color reaction applied to small samples of cormels, rather than by prolonged and indecisive germination trials.

The interaction between 2,3,5-triphenyltetrazolium chloride and living tissues produces a color reaction that appears to intensify in proportion to the degree of enzymatic activity. Primarily involved are dehydrogenases, which reduce the colorless tetrazolium salt to an insoluble red formazan (Mattson, Jensen, and Dutcher, 1947 ; Kun and Abood, 1949 ; Roberts, 1951; Brodie and Gots, 1952 ; Ried, 1952 ; Shelton and Schneider, 1952 ; Somerson and Morton, 1953 ; Jámbor, 1954 ; Jámbor and Mester, 1955 ; Schatz, Schatz, and Trelawny, 1956; Sorokin and Sorokin, 1956). By periodically rating this red coloration according to a standardized numerical scale, a picture of changing enzymatic activity within the cormel can be obtained. By subjecting cormels to various treatments and studying their tetrazolium reaction it is possible to predict, within limits, the effects of these treatments on germination. Since the TTC reaction in cormels is similar to reactions ob- 
served in seeds, it is possible that similar color patterns can be evolved for different seeds and their enzymatic activity studied during dormancy. A low degree of reddening need not merely infer a "loss of the capacity of the seed to germinate" as reported by Lambou (1953) for cotton seed, but could also indicate transitional stages between dormancy and germinability.

Examination of the literature on dormancy, and study of the reaction of gladiolus cormels to this colorimetric test have led to some speculations about the mechanism of their dormancy and germination. Davis (1930) indicated in her work on Xanthium seed that the development of dormancy is closely associated with restriction of oxygen supply by the fruit and seed membranes surrounding them. Barton (1934) found dormancy of Tilia seeds to be due to both an impermeable seed coat and a partially dormant embryo. The seed coats had to be rendered permeable and the embryo after-ripened before germination ensued. Thornton (1945) in a review on seed dormancy concluded that both initial (primary) and induced (secondary) dormancy may be oxygen phenomena. Each "has its inception ... in the accumulation of intermediate products, formed by partial anaerobic respiration, that act as inhibitors because the oxidation system has been temporarily impaired through an insufficient supply of oxygen." He suggested that high temperature storage augments dormancy because the hydrolyzing system remains active while the oxidation system is inhibited due to insufficient oxygen. Low temperature acts in the reverse fashion.

Many workers (Thimann and Skoog, 1933 ; Thimann, 1937 ; Lindner, 1939 ; Marth, 1942 ; Hitchcock, 1943 ; Smith, 1945; Link and Eggers, 1946 ; Leopold, 1949 ; Strydom, 1950) have shown that excess auxin can inhibit or prevent vegetative growth. The reduction of free-auxin content should encourage growth or the breaking of dormancy. Thus, Brandes and van Overbeek (1948) showed that breaking of dormancy and multiple sprouting in sugar cane induced by hot-water treatment were related to lowering of the freeauxin level. They suggested that dormancy is regulated by the free-auxin level and that a reduction of it preceded sprouting.

Larsen (1936) obtained an auxin-inactivating substance from the juice of bean seedlings. Larsen (1940) later demonstrated that the inactivation of the auxin by an enzyme occurred only in the presence of oxygen. This was also shown by Tang and Bonner (1947), who found that approximately one molecule of oxygen was consumed for each molecule of indoleacetic acid inactivated. Auxin (indoleacetic acid) inactivation was completely suppressed in the absence of oxygen. Recently Sequeira and Steeves (1954) reported that the leaf drop of coffee caused by Omphalia flavida Maubl. and Rang. resulted from auxin inactivation by an oxidative enzyme.

Stewart and Stuart (1942) stored Lilium longiflorum bulbs at $77^{\circ} \mathrm{F}$ under moist conditions for one month. The auxin level decreased until about the time that growth of stem tips and roots began, after which it increased at those points. Strydom (1950) showed that ethylene chlorohydrin broke the dormancy by lowering the free auxin level within gladiolus corms. He suggested a theory of dormancy in the gladiolus corm which is dependent on the amount of free auxin present. He showed that: when the free auxin level is high, corms are dormant; when the free auxin level is at the low or opti- 
mum range corms will sprout; and that when the free auxin level has been reduced drastically corms will not sprout, but may be induced to do so if indoleacetic acid is forced into them. When free auxin is reduced to the optimum level and dormancy is broken, growth may be initiated and auxin once again produced in the growing tips.

The normal cycle of dormancy in gladiolus cormels seems to be somewhat as follows: At digging time the tissues of the cormels are still active and the auxin level is presumably high, but not too high for the completion of growth and maturation. When the sheathing husks harden and thicken, oxygen is excluded from the internal cormel tissues, enzymatic activity diminishes, more free auxin accumulates, and growth gradually ceases (fig. 9). A period of dormancy ensues which may last for six months to two years, depending on the thickness of the husks or the rate of their deterioration. Dormancy during this time may be due to the relatively high auxin content within the cormel. One of several factors responsible for continued dormancy appears to be the lack of sufficient oxygen available to the enzyme systems responsible for diminishing free auxin. Dormancy may be effectively broken through partial destruction of free auxin by hot water or ethylene chlorohydrin treatment, and by oxidation after the husks are cracked (fig. 9 in Roistacher, Baker, and Bald, 1957) or the cormels are held in cold storage.

If no dormancy-breaking treatment is applied the cormels will remain dormant until deterioration of the outer husk allows penetration of oxygen, which will reduce the auxin level toward the optimum, break dormancy, and permit embryonic development to proceed.

It would appear that use of the TTC color rating as an indication of cormel germinability rests on the assumptions: 1) that dehydrogenase activity is measured by the intensity of coloration induced under standard conditions in the tissues of sampled cormels, and 2) that dehydrogenase activity and germinability are closely associated. How real this association is will perhaps be revealed by further studies on the enzymes involved in the liberation and degradation of free auxin (Larsen, 1940; Tang and Bonner, 1947). In the meantime, the empirical use of the test has given indispensable aid in the study of the reactions of cormels to hot-water treatment (Roistacher, Baker, and Bald, 1957). It has also been extensively used in later studies on the maturation and development of cormels (Bald and Markley, unpublished data). Probably it could be used also in similar investigations with true seeds.

As a routine technical test of the germinability of cormels, its future is not yet clear. It has been successful when applied by operators aware of its empirical nature and the conditions liable to induce aberrant readings. If, in the future, the enzymatic activity in cormels, as measured by the TTC color test, is linked closely to the initiation and development of root and stem apices, the test may become widely applicable. On the other hand, its practical use may be severely restricted if the color test is found to measure activity which is coincidental, but not directly connected, with these structural changes. 


\section{SUMMARY}

1. A technique has been presented for classifying various stages of dormancy in the gladiolus cormel. Briefly, the technique consists of longitudinally splitting 20 cormels, and placing the cut surfaces in contact with filter paper saturated with a 1 per cent solution of 2,3,5-triphenyltetrazolium chloride for 4 hours at $70^{\circ} \mathrm{F}$ in the dark. The cormel will react with the chemical and turn various shades of pink or red depending on its stage of dormancy.

2. A positive correlation has been found between the degree of tetrazolium coloration or reddening and the germination potential of gladiolus cormels.

3. Gladiolus cormels held in cold storage $\left(40^{\circ} \mathrm{F}\right)$ showed an increased tetrazolium reddening over a period of $5 \frac{1}{2}$ months, and this increase was positively correlated with increased germination of sister cormels planted at various intervals. However, cormels stored at room temperature showed no increase in staining during this period and no increase in germination when planted.

4. Cormels with the outer husks cracked had a higher degree of tetrazolium reddening and a correspondingly higher germination than uncracked ones from the same lot.

5 . Freshly harvested cormels showed a reddening reaction to the tetrazolium test which differed in appearance from those of mature cormels. This reddening disappeared completely after a period of time and was apparently associated with the drying and hardening of the outer sheathing husk. At the point of lowest tetrazolium reaction the cormels can be considered most dormant.

6. Larger cormels of a given lot showed a higher degree of tetrazolium reddening than the smaller ones and were, therefore, assumed to be less dormant.

7. The rate at which cormels increased in the degree of tetrazolium reddening varied with different varieties.

8. The tetrazolium test is a useful tool for determining the level of dormancy of gladiolus cormels and the correlated level of tolerance to heat treatment for the eradication of pathogens. Cormels appear to be most tolerant to the heat treatment when at maximum dormancy.

\section{LITERATURE CITED}

BARTON, L. V. 1934. Dormancy in Tilia seeds. Boyce Thompson Inst. Contrib. 6: 69-89.

Beal, J. M., W. H. Preston, JR., and J. W. Mitchell

1955. Use of 2,3,5-triphenyl tetrazolium chloride to detect the presence of viruses in plants. Plant Dis. Reptr. 39: 558-60.

BenNETT, N., and W. E. Loomis

1949. Tetrazolium chloride as a test reagent for freezing injury of seed corn. Plant Physiol. 24: 162-74.

BRANDES, E. W., and J. vaN OvERBEeK

1948. Auxin relations in hot-water-treated sugarcane stems. Jour. Agr. Res. 77: 223-38.

BREWER, H. E.

1949. Tetrazolium chloride as a test for damage in artificially cured peanuts. Science 110 : 451-52. 
Brodie, A. F., and J. S. Gots

1952. The reduction of tetrazolium salts by an isolated bacterial flavoprotein. Science 116: 588-89.

CURrier, H. B., and B. E. DAY

1954. The tetrazolium reaction in yeast. Science 119: 817 .

Davis, W. E.

1930. The development of dormancy in seeds of cocklebur (Xanthium). Amer. Jour. Bot. 17: 77-87.

Denny, F. E., and L. P. Miller

1934. Hastening the germination of dormant gladiolus cormels with vapors of ethylene chlorohydrin. Boyce Thompson Inst. Contrib. 6: 31-38.

Durrenoy, J., and R. Pratt

1948. Histo-physiological localization of the site of reducing activity in stalks of sugar cane. Amer. Jour. Bot. 35: 333-34.

DYAR, M. T.

1953. Studies on the reduction of a tetrazolium salt by green plant tissue. Amer. Jour. Bot. 40: 20-25.

Flemion, F., and H. Poole

1948. Seed viability tests with 2,3,5-triphenyltetrazolium chloride. Boyce Thompson Inst. Contrib. 15: 243-58.

Fred, R. B., and S. G. KNIGHT

1949. The reduction of 2,3,5-triphenyltetrazolium chloride by Penicillium chrysogenum. Science 109 : 169-70.

Fucris, W. H., and A. Beiler

1943. Über die Heisswasserempfindlichkeit der Karyopsen des Weizens. I. Deut. Bot. Gesell. Ber. 61 : 164-74.

1948. Die Anwendung der biochemischen Methode nach Lakon für die Saatgutprüfung bei heisswassergebeizten Weizen. Deut. Pflanzenschutzdienst Nachrichtenbl. 2: 127-29.

Fults, J. L., L. A. SchaAl, and M. E. Michaelson

1949. Value of the 2,3,5-triphenyl tetrazolium chloride reaction and ultraviolet light in parasitism studies of strains of Actinomyces scabies (Thaxt.) Guss. Soil Sci. Soc. Amer. Proc. 13: 287-91.

GERM, H., and M. KIETREIBER.

1954. Die Prüfung der Vitalität des Maiskornes. Bodenkultur 5: 29-47.

GoodSELL, S. F.

1948. Triphenyltetrazolium chloride for viability determination of frozen seed corn. Amer. Soc. Agron. Jour. 40: 432-42.

Gunz, F. W.

1949. Reduction of tetrazolium salts by some biological agents. Nature 163: 98 .

HITCHCOCK, A. E., and P. W. ZiMMERMAN

1943. Summer sprays with potassium a-naphthaleneacetate retard opening of buds, on fruit trees. Amer. Soc. Hort. Sci. Proc. 42: 141-45.

HuddLeson, I. F., and B. BALTzER

1950. Differentiation of bacterial species and variation within species by means of

JÁMBOR, B. 2,3,5-triphenyltetrazolium chloride in culture medium. Science 112: 651-52.

1954. Reduction of tetrazolium salt. Nature. 173: 774-75.

JÁMBOR, B., and L. MESTER

1955. Polarographic analysis of sugar tetrazolium derivatives and sugar formazanes. Acta Chim. Acad. Sci. Hungaricae 6: 263-73.

KUHN, R., and D. JERCHEL

1941. Über Invertseifen. VIII Mitteil. Reduktion von Tetrazoliumsalze durch Bakterien, gärende Hefe und Keimende Samen. Deut. Chem. Gesell. Ber., Abt. B, 74: 949-52.

Kun, E., and L. G. AвOOD

1949. Colorimetric estimation of succinic dehydrogenase by triphenyltetrazolium chloride. Science 109: 144-46. 
LAKoN, G.

1942a. Topographischer Nachweis der Keimfähigkeit der Getreidefrüchte durch Tetrazoliumsalze. Deut. Bot. Gesell. Ber. 60: 299-305.

1942b. Topographischer Nachweis der Keimfähigkeit von Mais durch Tetrazoliumsalze. Deut. Bot. Gesell. Ber. 60: 434-44.

LAмвоU, M. G.

1953. 2,3,5-triphenyltetrazolium chloride as a rapid indicator of viability in cottonseed. Science 117: 690-93.

LARSEN, P.

1936. Über einen wuchsstoffinaktivierenden Stoff aus Phaseolus-Keimpflanzen. Planta 25: $311-14$.

1940. Untersuchungen über den thermolabilen, wuchsstoffoxydierenden Stoff in Phaseolus-Keimpflanzen. Planta 30: 673-82.

LEOPOLd, A. C.

1949. The control of tillering in grasses by auxin. Amer. Jour. Bot. 36: 437-40.

LINDNER, R. C.

1939. Effects of indoleacetic and naphthylacetic acids on development of buds and roots in horseradish. Bot. Gaz. 100 : 500-27.

LiNK, G. K. K., and V. EgGers

1946. The effect of indoleacetic acid upon initiation and development of hypocotyledonary bud primordia in flax. Bot. Gaz. 108: 114-29.

MACLEOD, A. M.

1950. Determination of germinative capacity of barley by means of tetrazolium salts. Inst. Brewing Jour. 47 n.s.: 125-34.

MarTh, P. C.

1942. Effects of growth-regulating substances on shoot development of roses during common storage. Bot. Gaz. 104: 26-49.

Matpson, A. M., C. O. Jensen, and R. A. Dutcher.

1947. Triphenyltetrazolium chloride as a dye for vital tissues. Science 106: 294-95.

MoRse, R. E.

1949. Triphenyltetrazolium chloride as an indicator for blanching. Fruit Prod. Jour. 29: 13-14, 25, 29.

PARKER, J.

1953. Some applications and limitations of tetrazolium chloride. Science 118: 77-79.

1955. Effects of vital staining in Pinus ponderosa. Plant Physiol. 30 (Supplement) :x.

Porter, R. H., M. Durrell, and H. J. Rom M

1947. The use of 2,3,5-triphenyl-tetrazoliumchloride as a measure of seed germinability. Plant Physiol. 22: 149-59.

RIED, W.

1952. Formazane und Tetrazoliumsalze, ihre Synthesen und ihre Bedeutung als Reduktionsindikatoren und Vitalfarbstoffe. Angew. Chemie 64 : 391-96.

RoBerTs, L. W.

1950. A survey of tissues that reduce 2,3,5-triphenyltetrazolium chloride in vascular plants. Torrey Bot. Club Bul. 71: 372-81.

1951. Survey of factors responsible for reduction of 2,3,5-triphenyltetrazolium chloride in plant meristems. Science 113: 692-93.

Roistacher, C. N., J. G. BALD, and K. F. BAKER

1953. The tetrazolium test for dormancy and germinability of gladiolus cormels. Science 118: 186-87.

RoIstacher, C. N., K. F. BAKER, and J. G. BALD

1957. Hot-water treatment of gladiolus cormels for the eradication of Fusarium oxysporum f. gladioli. Hilgardia 26(17):659-84.

Schatz, A., V. Schatz, and G. S. Trelawny

1956. Antifungal properties of tetrazolium compounds. Mycologia 48: 473-83.

Sequeira, L., and T. A. Steeves

1954. Auxin inactivation and its relation to leaf drop caused by the fungus Omphalia flavida. Plant Physiol. 29: 11-16. 
Shelton, E., and W. C. Schneider

1952. On the usefulness of tetrazolium salts as histochemical indicators of the dehydrogenase activity. Anat. Rec. 112: 61-81.

SмITH, F. E.

1951. Tetrazolium salt. Science 113: 751-54.

SMiTh, P. F.

1945. Auxin in leaves and its inhibitory effect on bud growth in guayule. Amer. Jour. Bot. 32: 270-76.

Somerson, N. L., and H. E. MorToN

1953. Reduction of tetrazolium salts by pleuropneumonialike organisms. Jour. Bact. 65: $245-51$.

Sorokin, H. P., and S. Sorokin

1956. Staining of mitochondria with neotetrazolium chloride. Amer. Jour. Bot. 43: $183-90$.

Stewart, W. S., and N. W. StuarT

1942. The distribution of auxins in bulbs of Lilium longiflorum. Amer. Jour. Bot. 29: 529-32.

STRYDom, J. C.

1950. The effects of ethylene chlorohydrin on the rest period and auxin content of gladiolus corms. University of California, Los Angeles. 255 pp. (Thesis.)

TANG, Y. W., and J. BonNer

1947. The enzymatic inactivation of indoleacetic acid. I. Some characteristics of the enzyme contained in pea seedlings. Archives Biochem. 13: 11-25.

Thimann, K. V.

1937. On the nature of inhibitions caused by auxin. Amer. Jour. Bot. 24: 407-12.

Thimann, K. V., and F. Skoog

1933. Studies on the growth kurmone of plants. III. The inhibiting action of the growth substance on bud development. Natl. Acad. Sci. Proc. 19: 714-16.

THORnton, N. C.

1945. Importance of oxygen supply in secondary dormancy and its relation to the inhibiting mechanism regulating dormancy. Boyce Thompson Inst. Contrib. 13: $487-500$.

TsuKamoto, Y.

1954. Dormancy of gladiolus corms. I. Temperature treatment for the breaking of dormant gladiolus corms and its reaction to tetrazolium. Hort. Assoc. Japan Jour. 23: 16-20. (English summary.)

WAUGH, T. D.

1948. Staining of the stem tissue of plants by triphenyltetrazolium chloride. Science 107: 275 . 
The journal Hilgardia is published at irregular intervals, in volumes of abour 600 pages. The number of issues per volume varies.

Subscriptions are not sold. The periodical is sent as published only to libraries, or to institutions in foreign countries having pub. lications to offer in exchange.

You may obtain a single copy of any issue free, as long as the supply lasts; please request by volume and issue number from:

Agricultural Publications

Room 22 Giannini Hall

University of California

Berkeley 4, California

The limit to nonresidents of California is 10 separate issues on a single order. A list of the issues still available will be sent on request.

In our publications it is sometimes convenient to use trade names of products or equipment rather than scientific identifications. In so doing it is unavoidable in some cases that similar products which are on the market under other trade names may not be cited. No endorsement of named products is intended nor is criticism implied of similar products which are not mentioned. 